\title{
STEAM - PHYSICAL AND LITERARY COMPOSITION
}

Jana KALOV $\boldsymbol{A}^{*}$ *, Jihočeská univerzita v Č. Budějovicích, Česká republika

Valery Fedorovich OCHKOV, MEI, Moskva, Rusko

Alexey Victorovich SOKOLOV, Lyceum MEI, Moskva, Rusko

Julia Vladimirovna CHUDOVA, Lyceum MEI, Moskva, Rusko

Přijato: 30. 4. 2016 / Akceptováno: 25. 7. 2016

Typ článku: Teoretická studie

DOI: $10.5507 /$ jtie.2016.023

Abstract: Growing social demands on quality teaching in technical and natural science fields are accompanied with increased emphasis on reforms of education in those subjects. Simultaneously, the interest in improvement of attractiveness of teaching for students is increasing. Modern trends in teaching, labeled e.g. with known abbreviations STEM, STEAM, or STREAM, are dealt with by educational experts, teachers and some particular institutions as well. A connection of several fields in adequate expertise, difficulty and creativity puts new demands on teachers. In the presented paper, we will discuss the possibility and usefulness of united teaching of informatics, mathematics, physics and literature within one subject with a provisional title The physical-mathematical informatics.

Key words: STEAM, optics, mathematics, educational software, literature.

\section{STEAM - LITERÁRNĚ-FYZIKÁLNÍ KOMPOZICE}

Abstrakt: Rostoucí společenské požadavky na kvalitní výuku technických a prírodovédných oborů jsou doprovázeny zvýšeným důrazem na reformy ve výuce těchto předmètů. Současně se zvyšuje zájem o zvýšení atraktivity výuky pro studenty. Odbornici na vzdělávání, učitelé i některé instituce se zabývaji moderními směry ve vyučování, označovanými např. známými zkratkami STEM, STEAM či STREAM. Propojeni několika oborù v přiměrené odbornosti, náročnosti a kreativitě klade nové požadavky na učitele. V předkládaném př̀spěvku budeme diskutovat možnost a účelnost společné výuky informatiky, matematiky, fyziky a literatury v rámci jednoho předmětu s pracovním názvem fyzikálně-matematická informatika.

Klíčová slova: STEAM, optika, matematika, výukový software, literatura.

\footnotetext{
*Autor pro korespondenci: jkalova@prf.jcu.cz
} 


\section{1 Úvod}

V mnohých doporučeních, která vyplývají z výsledků nejrůznějších studií a průzkumů cílených na zjišt’ování zájmu o studium technických, př́rodovědných či matematických oborů, se objevují požadavky na zkvalitnění výuky zařazováním problémů vedoucích ke zvýšení motivace žáků a studentů. (Důvody nezájmu žáků o přirodovědné a technické obory. Výzkumná zpráva MŠMT, 2008).

Publikováno bylo mnoho prací zabývajících se přícinami klesajícího zájmu žáků a studentů o studium (nejen) technických a př́rodovědeckých oborů, popisujících důvody snižování úspěšnosti při jejich studiu a nabízejících cesty ke zlepšení (Rendl, Štech, 2012, Stokke, 2015). Často je diskutováno zařazování úloh z reálného života do výuky matematiky (Leong Yu Kiang, 2012).

V již zmíněné výzkumné zprávě Důvody nezájmu žáků o prrirodovědné a technické obory je uvedena zajímavá skutečnost, citujme: „Porovnání výsledků TIMSS (TIMS-Trends in International Mathematics and Science Study, projekt Mezinárodní asociace pro hodnocení výsledků vzdělávání IEA), MedVěd (Medializace a popularizace vědy, průzkum Př́rodovědecké fakulty Univerzity Palackého v Olomouci, 2007) a PISA (Programme for International Student Assesment, mezinárodní průzkum znalostí studentů organizovaný OECD) nám odhaluje zajímavý paradox. Češti žáci boduji v testech přirodovědných znalostí pomèrně dobře, nicménè tyto předmèty je nebaví, nemají je rádi. “"

Z mezinárodních srovnání tedy vyplývá, že studenti a žáci škol v České republice jsou dobře teoreticky připraveni, je ale třeba tyto předměty jim přibližit a studenty a žáky motivovat.

Autoři předkládaného článku zastávají stanovisko, že je důležité hledat cesty a metody k zatraktivnění výuky, ovšem udržet přitom v našich zemích stále ještě vysokou kvalitu a úroveň teoretických znalostí studentů a přesnost matematického vyjadřování. V souvislosti $\mathrm{s}$ diskuzemi o tom, co je vlastně matematické vzdělávání, $\mathrm{Wu}$ ve svém př́spěvku $(\mathrm{Wu}, 2006)$ rozebírá vztah mezi chemií a chemickým inženýrstvím, elektromagnetismem a elektroinženýrstvím, a odtud přechází k popisu matematického vzdělávání jako k matematickému inženýrství. Úlohou učitelů je podle $\mathrm{Wu}$,inženýrsky“ přibližit žákům a studentům abstraktní matematiku na príslušné úrovni. Avšak stejně jako strojní inženýr nemůže sestrojit perpetuum mobile, neměl by učitel, který je v roli vyučujícího matematického inženýra, učit nesprávně matematiku, připouštět nepřesnosti vyjadřování, nesprávnost použivaných matematických postupů či docházet $\mathrm{k}$ absurdním a nekorektním výsledkům.

Pro úspěšné vzdělávání $\mathrm{v}$ př́rodovědných a technických disciplínách, stejně jako pro přípravu budoucích učitelů těchto oborů, je nezbytná úzká spolupráce vědců (matematiků, fyziků, chemiků, IT specialistů atd.) a pedagogů. Studenti učitelství musí být vzděláváni tak, aby získali kvalitní teoretický základ ve svých aprobacích. Společně s tím je nezbytné, aby získali správné pedagogické a didaktické znalosti (a alespoň minimální zkušenosti př̀ praxích na školách) a naučili se respektovat didaktické zásady. Jistě není jednoduché nastavit správné proporce a rovnováhu mezi těmito požadavky (odbornost versus pedagogické dovednosti), nelze je však od sebe separovat. Jejich správné nastavení při príípravě budoucích učitelů je zásadní. 


\section{STEAM jako motivace $k$ technickému vzdělávání}

Koncem minulého století vznikl v USA vzdělávací směr STEM spojující prírodní vědy, technologii, inženýrství a matematiku. S rostoucím společenským tlakem na kreativitu a design je ke zmíněným předmětům zařazována také složka umělecká (odtud STEAM). $\mathrm{Z}$ doporučení $\mathrm{OECD}$ vyplývá také potřeba zkvalitnit výuku jazyka včetně písemného projevu. Pod jedním názvem STREAM jsou tak soustředěny obory Science, Technology, wRiting (současně i reading), Engineering, Art, Mathematics.

Uvedené vzdělávací směry mají své příznivce (Robelen, 2011, Root-Bernstein, 2011) i kritiky (Education for innovation, 2011). Autoři předkládaného článku si uvědomují rizika prŕstupu, který klade důraz na společnou výuku více předmětů (Schneider-Gilotová, 2006), a obávají se absence seriózních výzkumů, které by doložily účelnost a bezvýhradnost jejich aplikování při vzdělávání (Štech, 2013). Na druhé straně si uvědomujeme, že motivace žáků a studentů je velmi účinným nástrojem pro zkvalitnění výuky, dosažení požadovaných cílů vzdělávání a současně pro zvýšení zájmu žáků a studentů i o obtížnější školní předměty a kurzy. Podle Pavelkové et al. (Pavelková, Hrabal K., Hrabal V., 2010) je motivace k učební činnosti jedním z nejdůležitějších předpokladů školního výkonu žáka.

Podle psychologických teorií jsou motivem lidského chování a jednání potřeby (Homola, 1977, Nakonečný, 2009, Hartl, Hartlová, 2010). Pro vymezení a definici pojmu potřeba lze najít v literatuře několik prrístupů. Často se používá rozdělení hierarchické (Maslow, 1954), jindy se potřeby člení na organické a psychické, primární a sekundární (podrobně Murray, 1938). Protože každý člověk je jedinečnou osobností, je i souhrn jeho potřeb unikátní, navíc dynamický, s časem se měnící. Motivací k dosažení cíle a uspokojení potřeb, a to motivací vnější i vnitřní (Hayes, 2003, Čáp, Mareš, 2007), může být pro někoho umělecké nebo literární dílo, pro jiného sportovní výkon, pro dalšího např. úspěšné vyřešení nějakého problému.

Motivování žáků a studentů je složitý proces. Nevhodnou volbou motivačních metod může dokonce učitel vyvolat odpor $\mathrm{k}$ vyučovanému předmětu. Stejně jako pro dosažení optimálních výsledků vzdělávání má záporný vliv nuda př̀i vyučování, může být naopak problémem přetěžování studentů kladením neúměrných požadavků nebo také nadměrná motivace (Lokšová, Lokša, 1999). Pro optimální motivování je nutné znát a rozpoznat dominující potřeby a zájmy studenta (Hrabal, Man, Pavelková, 1989), což je ovšem velmi individuální záležitostí.

Jako příspěvek k zatraktivnění výuky a motivování studentů středních a vysokých škol při dodržení požadavku její vysoké kvality a přiměřené náročnosti i abstrakce se objevují náměty ke společné výuce informatiky, matematiky a fyziky (Ochkov, 2015). Tato forma není zcela nová, už v třicátých letech minulého století přednášel na MIT (Massachusetts Institute of Technology) jeden ze zakladatelů kybernetiky Norbert Wiener společně o elektrotechnice a matematice. Kromě technických disciplín a matematiky je možné zahrnout do společné výuky také literaturu (Ochkov V.F., Look A., 2015). Nabízí se tak (alespoň pro některé studenty) velmi zajímavý prostor pro studium teoretických, uměleckých, historických a obecně kulturních aspektů nějakého konkrétního problému, následně lze prripravit vhodný experiment a jeho interpretaci, a nakonec vytvořit a analyticky nebo numericky realizovat matematický a fyzikální model zkoumaného procesu. 


\section{Představení a metodika projektu}

Cílem naší práce bylo ověrit v praxi jednu z mnoha lekcí, které máme připraveny pro výuku v kontextu STEAM (Ochkov et al., 2016), zjistit vliv takového způsobu výuky na zvýšení motivace studentů ke studiu fyzikálního problému, a následně řešit fyzikální problém nastíněný $\mathrm{v}$ motivační fázi výuky použitím matematických metod $\mathrm{s}$ využitím informačních technologií.

Nastíníme obsah lekce a předvedeme, jak lze námět využít ve výuce. Téma je vhodné pro starší středoškoláky a pro studenty prŕslušných oborů vysokých škol. Poznamenejme zde, že téma, které $\mathrm{v}$ této ukázkové lekci předvedeme, patř́i pro středoškoláky v ČR mezi ty náročnější, na rozdíl od Ruska, kde je vykládáno na lyceu.

Kombinace využití uměleckých, matematických, fyzikálních a IT dovedností ve výuce kladou velké nároky na studenty i učitele. Práce s každým studentem je ryze individuální. Statistické vyhodnocení a vyvození relevantních obecných závěrů pro širší populaci je velmi obtížné. Objektem zkoumání byli studenti technického lycea v Moskvě a v menší míře také studenti v magisterském studiu učitelských oborů na Jihočeské univerzitě. Do zkoumání jsme tedy zahrnuli studenty různého věku a různých studijních oborů. Proto jsme použili kvalitativní empirickou metodu zkoumání, převážně pozorování a rozhovor, kdy jsme se snažili zjistit př́nos popisovaného způsobu výuky pro jednotlivé studenty.

\section{Modelový příklad výuky STEAM}

Na základě našich zkušeností s několika skupinami studentů a různými náměty STEAM jsme navrhli a vyzkoušeli následující postup výuky.

Lekci jsme začali uměleckou složkou, literaturou. Populárním žánrem beletrie je detektivní př́iběh popisující jakýsi záhadný zločin, který je chytře odhalován profesionálním nebo amatérským detektivem. Zajímavé detektivní príiběhy lze najít v díle Karla Čapka. Jeden z prŕiběhů jsme zvolili pro naši ukázkovou lekci. V Čapkově povídce $O$ kasaři a žháři je odhalována př́íčna tajemného požáru, jehož příčinou byla lupa šikovně umístěná učněm vlastníka domu, podle kterého učeň nebyl k žádné práci, protože měl v hlavě samé takové hlouposti a jiné pokusy. Učeň podle svých výpočtů bez astronomických př́strojů natočil lupu tak, aby při sluneční kulminaci očekávané za několik měsíců zapálila slámu.

V první fázi výuky se studenti seznámili s povídkou. Podle toho, jaký čas je možný výuce daného tématu věnovat, lze tuto fázi ve výuce omezit na několik minut. Tomu ale musí předcházet zadání domácího úkolu studentům, kteří by se s př́iběhem měli předem seznámit. Ve škole pak lze během krátké doby př́iběh zrekapitulovat. Tuto fázi zvládnou studenti sami, učitel jen zadá téma - detektivní př́běh.

Následovala fyzikální část (podrobný popis fyzikálního problému a jeho řešení lze nalézt v publikaci Ochkov, Kalová, Sokolov, Chudová, 2016). Zformulovali jsme tedy fyzikální zadání úlohy. Jako vazbu na praxi připomeňme zde i při výuce, že znalost zákonů a principů geometrické optiky se využívá např. při návrzích radioteleskopů, při činnosti geotermálních stanic jsou využívána zrcadla řízená počítačem, $v$ divadlech či filmovém průmyslu jsou použivány světlomety. $\mathrm{V}$ této fázi je důležitá zodpovědná příprava učitele, který musí problematiku odborně zvládnout a se studenty na odpovídající úrovni správně a přesně rozebrat. Tato fáze, opět $\mathrm{v}$ závislosti na čase, který máme se studenty $\mathrm{k}$ dispozici, zabere 
zhruba jednu hodinu. Studentům lze poté zadat k domácí práci vyhledání některých pojmů a principů, které se $\mathrm{v}$ další fázi využijí $\mathrm{k}$ vyřešení problému.

Při řešení úlohy se studenty jsme využili fyzikální zákony a geometrické vztahy. Následně jsme stanovili matematický model ve tvaru diferenciální rovnice. Oči, kterými člověk získává podstatnou část informací o okolním světě, nejsou nic jiného, než dokonalé optické př́istroje, které často opravujeme a zesilujeme podobnými př́stroji, jako je monokl, lorňon, brýle, sluneční brýle, dalekohled, periskop, mikroskop, teleskop, atd. Dáme-li dohromady matematiku, fyziku a literaturu, tedy základní školní předměty, se současnými informačními technologiemi, lze úspěšně a hlavně zajímavě řešit skutečně složité optické úlohy, a současně zkoumat zákony matematiky, fyziky a seznámit se s literární tvorbou.

Model jsme řešili analyticky a také numericky, použili jsme i matematický software a všechny výsledky jsme porovnali (výsledky popsány v Ochkov et al., 2016). Matematický software umožnil měnit parametry modelu, experimentovat s nimi a rychle získávat výsledky. V této části výuky je výhodné umožnit studentům pracovat ve skupinách $\mathrm{i}$ individuálně. Některé z částí řešení problému lze opět předem zadat $\mathrm{k}$ domácímu nastudování. Také tato etapa ovšem vyžaduje pečlivou př́pravu učitele.

Závěrečným stádiem lekce byla interpretace výsledků, jejich shrnutí, zdůraznění nosných částí problému a jejich zobecnění. Na tomto procesu se společně podíleli studenti a učitel.

Autoři předkládaného př́spěvku mají bohatou praxi $\mathrm{s}$ výukou a také $\mathrm{s}$ vědeckým výzkumem v technických disciplínách. Uvědomují si, že ve středoškolské i vysokoškolské výuce (nejen) optiky se často využívají předem připravené vztahy, které mnozí studenti používají podobně jako vzorečky při řešení matematických úloh, bez hlubších znalostí a bez pochopení významu či odvození. Proces vzdělávání se pak nezaměruje na zkoumání základních principů např. optiky, ale na memorování již připravených vzorců na výpočet ohniskových vzdáleností, dioptrií, koeficientů zvětšení či zmenšení atd. My v naší lekci se studenty př́islušné vztahy hledáme a tvoříme model, v př́ípadě úlohy o čočce jsme hledali tvar jejího povrchu. Současné výpočetní prostředky a technologie umožňují vynechat mnohá zjednodušení a počítat optické přístroje přesněji. Lze použít specializované programy nebo nějaký univerzální matematický software. My jsme pracovali se softwarem MathCad. Po počátečním váhání studenti matematický software pro řešení nastoleného problému bez problémů využili.

\section{Výsledky a diskuze}

Popsanou lekci jsme vyzkoušeli ve výuce. Naše zkušenosti ukazují, že studenti tento typ vyučování hodnotí víceméně pozitivně, ačkoliv ne shodně. Velmi záleží na individualitě studenta. Umělecky orientovaní studenti se zájmem studovali literární předlohu a alespoň zpočátku sledovali i matematické a fyzikální řešení problému. Studenty technicky zaměřené naopak literární část př́liš nezaujala. Vzorek studentů, s nimiž jsme pracovali, byl poměrně široký, pracovali jsme se studenty středních i vysokých škol rozličných studijních zaměření. Výuka byla projektová, studenti se zapojovali do výuky podle svých schopností, možností a zájmů. Protože vzorek studentů není doposud dostatečně reprezentativní, je předčasné vyslovovat obecné závěry. Domníváme se však, že stejně jako ve výzkumech podobného typu, zaměřených na identifikaci společných znaků, př́nosů a problémů (Vondrová et al., 2016), není tato skutečnost zásadní. 
Nemyslíme si, že je možné naučit každého studenta fyziku či matematiku na vyšší úrovni, ani to není naším cílem. Jsme ale přesvědčeni, že v motivační fázi výuky lze zaujmout napřr. literárním žánrem studenty, kteří $\mathrm{k}$ technickým a př́rodovědným předmětům nemají př́iliš kladný vztah. Je možné, že $\mathrm{v}$ některých případech i studenti zaměření spíše na společenskovědní obory, $\mathrm{v}$ etapě motivování a přípravy $\mathrm{k}$ následnému zkoumání fyzikálních nebo matematických jevů naleznou nějaké přitažlivé prvky. Naopak se může stát, že student zaměřený vyloženě na technické obory, matematiku nebo informatiku, popsanou motivační fázi přeskočí, protože ho nebude bavit ani zajímat, a soustředí se přímo na vlastní studium nastoleného problému. Tyto předpoklady se i na našem malém vzorku potvrdily, a jsou v souladu spsychologickými a pedagogickými výzkumy cílenými na úspěšnost studentů v souvislosti s jejich zájmy či styly jejich učení.

Při práci studentů jsme pozorovali další zajímavý prvek. Někteří studenti se zaměřili na vyhledávání řešení na internetu nebo oslovili specialisty na odborných fórech. Zadání úlohy bylo dokonce umístěno na stránky PTC community / Mathcad se záměrem počkat, až problém někdo vyřeší. Evidentně tedy někteří studenti ani při používání nejrůznějších výukových metod výukové problémy řešit vlastními silami nebudou. Někteř́ z nedostatku zájmu, jiní z nedostatku schopností (Wyckoff, 2001).

Někteří př́znivci a propagátoři výuky $\mathrm{v}$ kontextu STEAM zastávají stanovisko, že studenti, kteří studují umělecké obory, lépe zvládnou i obory technické (Robelen 2011, Root-Bernstein, 2011). Naopak odpůrci společné výuky oborových předmětů a STEM (Education for innovation: the role of arts and STEM education, 2011) poukazují na výsledky výzkumů, podle kterých je nutné obory oddělit a vyučovat strukturovaně. Oba tyto směry se pak střetávají při tvorbě, uplatňování i kritikách školského kurikula (Štech, 2013). My se přikláníme $\mathrm{k}$ názoru, že $\mathrm{v}$ motivační fázi výuky je vhodné použít jakékoliv vyhovující metody $\mathrm{k}$ navození pracovní atmosféry a $\mathrm{k}$ př́ípravě studia konkrétní odborné oborové problematiky. Současně jsme si vědomi odlišností v myšlení, stylech učení se i v zájmech studenti̊, a jsme také seznámeni s vědeckými pracemi poukazujícími na nezbytnost diferencovaného př́istupu k učivu (např. Young, 2007).

\section{Závěr}

Uvědomujeme si, že na učitele jsou kladeny velké nároky i bez požadavků vyučovat v kontextu STEAM. Často nemají patřičné znalosti, a vzhledem k rozsahu výuky v souvislostech STEAM ani mít tyto znalosti nemohou (Kalová, 2014). Diskutabilní je také otázka, jak jsou na výuku at' už v kontextu STEM, STEAM, STREAM nebo badatelském připravováni studenti oborů na fakultách připravujících učitele. $V$ další fázi naší práce budeme pokračovat ve zveřejňování námi již nyní připravených lekcí STEAM. Plánujeme nějakou z našich dalších lekcí opět vyzkoušet při různých formách výuky. Nabízí se napřs. možnost pracovat tímto způsobem $\mathrm{v}$ rámci zájmových kroužků nebo samostatných studentských projektů (Kalová, 2013). V souvislosti s Vyhláškou o vzdělávání žáků se speciálními vzdělávacími potřebami a žáků nadaných (Předpis č. 27/2016 Sb.) budou mít školy zákonnou povinnost připravovat individuální studijní plány nadaným žákům a studentům. Také pro tyto účely bude $\mathrm{v}$ některých prípadech vhodné podobné vzdělávací metody využívat. 
Připomeňme zde závěr Čapkovy povídky: ...jaký by z toho uličnika mohl být hvězdár nebo fyzik. Vždyt’ to mohl být druhý Newton nebo co, ten zatracený kluk! Ale ono na svètě přicházi nazmar tolik zvláštního dưmyslu a takových těch krásných schopností - víte, lidé mají tu trpèlivost hledat $v$ pisku diamanty nebo perly $v$ moři; ale aby hledali v lidech vzácné a podivné dary od pánaboha, aby nepřšlly nazmar, to je ani nenapadne. A to je veliká chyba.

Nadále spolupracujeme na mezinárodní úrovni, připravujeme další projekty podporující motivování studentů ke zvýšení zájmu o prýrodovědné a technické obory.

\section{Literatura}

Čáp, J., \& Mareš, J. (2007). Psychologie pro učitele. Praha Portál.

Čapek K. (2007). Povidky z druhé kapsy. Fragment.

Di̊vody nezájmu žáků o přirodovědné a technické obory (2008). Výzkumná zpráva MŠMT.

Dostupné

http://www.generacey.cz/uploads/akce_a_aktuality/pardubicky_kraj/Duvody_nezajmu_zak u.pdf

Education for innovation: the role of arts and STEM education (2011). The OECD/France Workshop. Dostupné z: https://www.oecd.org/edu/ceri/oecdfranceworkshopeducationforinnovationtheroleofartsandstemeducation.htm

Hartl, P., \& Hartlová, H. (2010). Velký psychologický slovnik. Praha Portál.

Hayes, N. Aplikovaná psychologie (2003). Praha Portál.

Homola, M. (1977). Motivace lidského chování. 2. vyd. Praha SPN.

Hrabal V., Man F., \& Pavelková I. (1989). Psychologické otázky motivace ve škole. Praha: SPN.

Kalová, J. (2013). Samostatné studentské práce jako prostréedek pro zvýšeni zájmu o technické a prírodovědné obory. JTIE Vol. 5/2. Olomouc.

Kalová, J. (2014). Aplikační úlohy ve výuce matematiky na SŠ? Sborník z konference, MITAV, Brno.

Leong Yu, Kiang (2012). Mathematics K12: Crisis in Education. Interview with Wu HungHsi. Mathematical Medley, Vol. 38, No.1. Dostupné zWWW: https://math.berkeley.edu/ wu/Interview-MM.pdf

Lokšová, I. \& Lokša, J. (1999). Pozornost, motivace, relaxace a tvořivost dětí ve škole. Praha Portál.

Maslow, A. H. (1954). Motivation and personality. New York: Harper and Row.

Murray, H. A. (1938). Explorations in personality. Oxford, England: Oxford Univ.

Nakonečný, M. (2009). Sociální psychologie. Praha Academia. ISBN 978-80-200-1679-9.

Ochkov V.F. (2015). Programmnoje uravnenije ili FMI. Cloud of Science 2/3, 473-515.

Dostupné z WWW: http://twt.mpei.ac.ru/ochkov/PMI.pdf

Ochkov V.F., Kalová J., Sokolov A.V., \& Chudova J. (2016). Literaturno-fiziceskaja kompozicija „Istorii o zerkale $i$ lize“. Otkrytoje obrazovanije. Pavelková, I., Hrabal, K., \& Hrabal, V. (2010). Mezinárodní srovnání motivačních zdrojů učebni činnosti žákủ. Pedagogika, roč. 60, č.3-4, s. 292-302.

Rendl, M., \& Štech S. (2012). Should Learning (Mathematics) at School Aim Knowledge or at Competences?, Orbis Scholae, 6 (2), 23-29. 
Robelen, E. W. (2011). STEAM: Experts Make Case for Adding Arts to STEM. Dostupné z: http://www.edweek.org/ew/articles/2011/12/01/13steam_ep.h31.html

Root-Bernstein, R. \& Root-Bernstein, M. (2011). Turning STEM into STREAM: Writing as an Essential Component of Science Education. Dostupné z: http://www.nwp.org/cs/public/print/resource/3522

Schneider-Gilot, M. (2006). Quand le courant pédagogique " des compétences 》 empêche une structuration des enseignements autour de l'étude et de la classification de questions parente. Dostupné z: https://rfp.revues.org/136

Stokke A. (2015). What to do about Canada's declining math score. C.D.Howe institute, Commentary No. 427.

Štech S. (2013). Když je kurikulární reforma evidence-less. Pedagogická orientace, roč. 23, č.5, s. 615-633.

Vondrová N. et. al. (2016). Kritická mista matematiky základní školy. Karolinum.

$\mathrm{Wu}, \mathrm{H}$. (2006). How mathematicians can contribute to $K-12$ mathematics education. Proceedings of International Congress of Mathematicians, Madrid. Vol. III, European Mathematical Society, Zürich, 1676-1688.

Wyckoff, S. (2001). Changing the culture of undergraduate science teaching. Dostupné z: http://www.nsta.org/publications/news/story.aspx?id=41157

Young, M. (2007). Bringing knowledge back in: From social constructivism to social realism in the sociology of education. London and New York: Routledge. 